\title{
Does My Business Need a Human Resources Function? A Decision-Making Model for Small and Medium-Sized Firms
}

\author{
Golbou Ghassemieh
}

Liz Thach

Armand Gilinsky

$T$ The questions of when and what types of human resource (HR) support are needed tend to be unanswerable for small and medium-sized enterprises (SMEs). This article addresses this gap in the strategic HR literature. Hiring, training, employee retention/satisfaction, wages and benefits programs, and worker's compensation insurance are important to SMEs seeking to build strong capabilities and resources and to increase their competitive advantage. This article presents an analysis of the existing HR literature for SMEs. It introduces a decision model to help SMEs choose a cost-effective HR strategy, listing a range of options from biring the HR function to electronic HR (eHR) and outsourcing

Town Grocery, a company with 350-plus employees in Northern California, is an example of a local medium-sized business with no Human Resources (HR) Department. ${ }^{1}$ Management, as well as lower level employees, have questioned the lack of HR at Town, and have yet to find a resource that points to an answer. It is not uncommon for small and medium-sized enterprises (SMEs) to ask when a formal HR function should be added to their administrative/overhead cost structures. Town, a typical community-based business, is a slow growth business, with plans to open a third store sometime in the future. Management is clearly facing a number of costly problems, such as numerous worker's compensation claims, higher worker's compensation insurance premiums, and a lack of adequate store training, among others. The management team at Town has divided various aspects of classic HR tasks among itself and other store administrators. This is a typical strategy of SMEs; however, the team not only lacks adequate HR training, but also has spread itself too thin. These issues, not uncommon to small businesses that lack HR, are preventable and resolvable-if the most costeffective HR strategy is identified and implemented.

SMEs are defined by the number of workers employed: 1-100 is considered small; 101-5,000, medium (Wager and Langrock 2003a; Hornsby and Kuratko 2003). Town Grocery is one of an estimated 15 to 17 million SMEs in the United States (Case 2001). SMEs employ an estimated 60 percent of the total U.S. workforce (Watson and Everett 1993; Appelbaum and Kamal 2000). Despite their disproportionately large role as employers in the U.S. economy, SMEs tend to have a very high failure rate-approximately 80 percent in the first 10 years of business (Ibrahim and Ellis 1993; Appelbaum and Kamal 2000). SMEs are more likely to survive and sustain a competitive advantage over larger rivals via increasing employee satisfaction, which, in turn, minimizes turnover, absenteeism, and lost productivity costs (Porter 1990; Appelbaum and Kamal 2000). Implementing a strategic HR function in SMEs thus can be a key element to increasing competitive advantage (Augustine and Wilson 1994; Huselid 1995; Klass et al. 2002).

SMEs that can afford to staff an HR function may also prevent costly mistakes. For example, each time a poorly trained employee misinforms a customer or handles a sale incorrectly, money is lost and in a "worst-case" scenario, a lawsuit may ensue. When employees lack simple safety training, otherwise preventable injuries can occur, resulting in increasing worker's compensation claims and higher insurance premiums. A well-designed HR function can resolve employee grievances; deal with employee benefits, training, worker's compensation cases; and implement team-building activities to strengthen the internal network, as well as handle many other employee-related issues. Though large corporations have a multitude of options when it comes to choosing and implementing HR functions, SMEs face significant hurdles to making an investment in HR functions or outsourcing those to consulting firms. These challenges include: inability to reach economies of scale, lack of revenue scale, and insufficient cash flow (Klass 2003).

The next section presents an analysis of the literature about the extant options for implementing HR in SMEs. The options range from hiring for an HR function or formal department, to electronic/internet-based HR (eHR), to outsourcing.The article closes with an examination of a decision model to help SMEs make more informed decisions and a discussion of how practitioners can use this model to develop and implement an HR strategy.

\section{Relevant Research Orientations}

Human Resource Management (HRM) is defined as the "process of attracting, developing, and maintaining a talented and energetic workforce to support organizational mission, objectives, and strategies" (Schermerhorn 2001: 240). There are two aspects of managing human resources, the administrative and the strategic. The administrative side of $\mathrm{HR}$ is more tactical, including tasks such as filing hiring paperwork, 
payroll, benefits and compensation enrollment (Davidson 2003). Strategic HR acts as a business partner to overall business management by providing employee retention strategies, talent management, and other services that add value to the company's business strategy (Davidson 2003).

According to Porter (1990), the human resources function is the backbone of organizational strategy and competitive advantage. Small business managers are faced with the same organizational issues that need to be addressed by managers of larger corporations (e.g., job specialization, departmentalization, chain of command, span of control, centralization and decentralization, and formalization) (Robbins 2000). How these questions are answered typically depends on the size of the organization, its stage of growth, and the company's chosen industry environment.

Many SMEs choose a simple structure, characterized by wide spans of control, authority centralized in a single person (usually the manager/owner), and little formalization (Robbins 2000). Simple structures and low levels of departmentalization are said to account for the agility and flexibility of SMEs (Harel and Tzafrir 1999; Cassel et al. 2002). Simplicity of form and function also carry attendant risks of information overload at the top level of the organization as well as an overreliance on the manager/owner for direction (Hornsby and Kuratko 2003). The multifarious responsibilities and pressures that SME managers/owners face thus present a time management dilemma. Much of the stress of handling employee relations and practices can be alleviated through some form of HRM implementation, allowing managers/owners to have the time needed to handle more important or cost-effective tasks (Krieger 2003). Ideally, managers/owners should have the freedom to focus their energies on business strategy, on improving their awareness of the industry and the competitive environment, on the financial underpinnings of their businesses, and on marketing efforts; essentially, on conducting the "business of the business" (Krieger 2003).

For most SME managers/owners, implementing HR functions without sufficient expertise can be a risky proposition given the nature and severity of compliance laws such as EEOC,ADA, COBRA, OSHA, INS, etc. (Krieger 2003). Major HR functions include: (1) recruiting and hiring, (2) training and motivation, (3) compensation and benefits, and (4) developing metrics to gauge the contribution of intangible human assets to enterprise value. The extant literature regarding how those major functions are performed is examined below in greater detail.

\section{Recruiting and Hiring}

What attracts workers to a small business in the first place? Some researchers argue that the lack of formality breeds a more personal environment with better relationships, others are not convinced that better relationships exist in SMEs (Rowden 2002a; Vinten et al. 1997). Despite the appeal of a close-knit work environment in the smaller firm, employee recruitment is the top concern for owners and managers of SMEs; this is, in part, due to high staff turnover and limited pools of qualified candidates (Hornsby and Kuratko 2003). A study of Canadian SMEs shows that 51 percent of respondents rely on the president or chief executive officer to hire employees, 31 percent rely solely on the owner of the business, and 18 percent have a manager or other employee assigned to the task of recruitment (Wager and Langrock 2003a).

Healthy interpersonal relationships at work also appear to be positively associated with increased employee efficiency (Vinten et al. 1997). For most SMEs, recruiting is largely the responsibility of senior management, or sometimes lowerlevel employees (i.e., who are not trained in recruitment practices) (Wager and Langrock 2003a). The standard cost of losing an employee for SMEs, one half times the employee's annual salary, is considered costly given the limited resources available to many SMEs (ASTD 2003; Saratoga Institute 2003). However, few empirical studies have been conducted on the hiring practices of SMEs, and little is known about HR hiring practices in very small businesses (Wager and Langrock 2003a).

\section{Training and Motivation}

Once a small business has recruited and hired employees, keeping them trained and motivated to be productive in their jobs can be challenging. Yet, research has shown that a "wellmotivated, highly skilled workforce is a determinant of a small firm's ability to remain competitive in the contemporary business environment" (Hornsby and Kuratko 2003: 2).

Other research has also shown that employee training is a similarly important determinant of growth, though SMEs are sometimes reluctant to train employees who may not stay (Wager and Langrock 2003b). Workplace training, a factor that has been shown to correlate highly with employee satisfaction and turnover, is often less accessible to small employers than to large corporations (Devins and Johnson 2003). Although employee retention is affected by low pay, it is more impacted by "inadequate job/personal satisfaction" (Appelbaum and Kamal 2000).

Increased customer satisfaction, higher sales, and improved technical skills are often worth the extra financial outlay to train staff (Vinten et al. 1997).Two empirical studies indicate that the training practices of SMEs in the United States have not changed in over a decade (Hornsby and Kuratko 2003). While researchers agree intuitively that training positively impacts both sales and growth of SMEs, empirical research on SMEs to date has yet to substantiate this claim (Rowden 2002a). Clearly, more research in how SMEs 
train staff and the resultant impact on firm performance is warranted (MacMahon and Murphy 1999 ).

Finally, though company training and development is a key factor in promoting employee motivation, research has also shown that job satisfaction is positively impacted by the level of employee autonomy, team or group cohesion, relationships and trust, and organizational culture or climate (Appelbaum and Kamal 2000). SMEs need to keep focused on these important elements as well as create an environment that enhances motivation.

\section{Compensation and Benefits}

After recruitment, hiring and training, employee compensation and benefits are the next highest concerns among owners and managers of SMEs (Hornsby and Kuratko 2003). While most SMEs cannot afford to pay corporate salaries (Rowden 2002a), there is some evidence that employee equity compensation has a positive impact on growth of SMEs (Arbaugh et al. 2004). Compensation is perhaps the most obvious incentive for employee retention and productivity, however other equally effective motivators have been identified, including commitment to the company's vision, the job itself, skill level, and performance recognition (Huselid 1995; Burke 1997).

Many SMEs are starting to offer incentives such as year-end bonuses, profit-sharing plans, stock options, and "gainsharing" (Welbourne et al. 1995; Graham and Welbourne 1999; Shutan 2003; Arbaugh et al. 2004). However, employees are more concerned about receiving health insurance and worker's compensation benefits. Since an estimated 42 million Americans are without health insurance at the time of this writing (Hill 2004), a core issue for public policy is to what extent the private sector should be responsible for its workers' health. For many SMEs the costs associated with providing health insurance are significant. Self-funding and network providers are some lower cost options; however, SMEs need to consider how to rate those services for coverage options for medical and dental insurance (Shutan 2003). Worker's compensation premiums are often even more costly than health insurance. Rates are usually based on company safety records, which emphasizes the importance of internal safety programs, another function that rolls into HRM (Shutan 2003).

Concomitant to fostering a positive working environment and intrinsic motivators, compensation should match the work that employees perform. There is a need for clarity when it comes to job duties, employee expectations, and compensation. (Appelbaum and Kamal 2000). A job description that matches the realities of the job is necessary and used by employees when developing their perception of equitable pay. Beyond job descriptions, experts recommend that SMEs "contact an accountant, trade association, the
Bureau of Labor Statistics (BLS), or a combination thereof to determine appropriate salaries, cost ratios, and profit margins" (Shutan 2003: 2). Knowing how competitors measure up in their compensation packages is important and valuable information for owners and managers of SMEs. Benchmarking is a useful and needed tool in developing compensation (Shutan 2003).

\section{HR Metrics and Enterprise Value}

Many SMEs view human resources as a "process and a cost" (Mathis 2003). However, the role of HR in organizations is increasingly becoming more of a strategic business partner than a formal administrative function (Becker et al., 2001; Davidson 2003; Becker and Huselid 2003). As a consequence, HR metrics organizations, such as the Saratoga Institute and the Society for Human Resource Management (SHRM), offer their metric consulting services to firms who want to see the cost-benefits analysis of their HR departments (Becker et al., 2001; Davidson 2003).

A recent study shows that 85 percent of a company's assets are intangible, and 43 percent of HR competencies provide a strategic contribution. Thus, deriving the allocable HR costs and contributions can be key to the overall valuation of an enterprise (Weatherly 2003). According to the Saratoga Institute (2003), other important HR metrics include HR staff per employee, HR cost per employee, time to fill a position, and cost per new hire. In 2000, the average HR fulltime equivalent ratio, a ratio that measures the number of fulltime employees per HR person, was 90:1 (Davidson 2003). Although this ratio varies by industry and over time, it speaks to the importance of human resources in deriving enterprise value and the need for SMEs to revisit some of the trade-offs between labor intensity and capital intensity, inasmuch as SMEs consider their employees to be as either costs or assets (Gering 2003).

By way of example, a "firm's $\$ 100$ cash flow had a market value of $\$ 2,000$, while [its] largest competitor's $\$ 100$ cash flow had a market value of $\$ 4,000$ " (Becker et al. 2001:5). The difference in valuation was a result of the efficiencies that the rival firm had created from strategic management of HR. When the suggestion was made to evaluate the lower valued firm's HR to help increase its market value, that firm's executive expressed his lack of concern for HR functions and measurements, stating that his system was cost effective and did not need to be measured. As it turned out, his firm was subsequently acquired by its rival! Proactive measures to help SME executives understand "the connection between investments in HR architecture and shareholder value," might have produced a different outcome (Becker et al. 2001: 6).

To optimize the value of a firm's HR assets and reduce the associated costs, Saratoga Institute (2003) has developed guidelines for return on investment (ROI) analysis. These 
include: (1) identifying all of the direct and indirect costs associated with HR programs, processes, and activities; (2) assessing quantifiable results; and (3) using those results in the analysis (Davidson 2003). SMEs appear to have potentially high stakes with regards to the effects of an HR strategy on enterprise value, as valuations are used for purposes of obtaining bank loans, investment capital, sale or exit planning, or even tax planning for succession in family-owned and/or family-run firms (Welbourne and Cyr 1999a).

Based on the above review of the literature on HR in SMEs, there are several gaps in our understanding of strategic HR functions and choices for SMEs. As SMEs deserve a clear understanding of how and to what extent they need to make an HR strategy part and parcel of an overarching business strategy, we now turn to the proposed decision-making model.

\section{HR Decision Model for Small and Medium-Sized Enterprises}

Once a SME hires employee number one, an HR strategy is born, either as part of planned strategy or as an emergent, unintended consequence of growth. To create an effective HR management system, SME owners and managers must have a clear understanding of the future needs of their business and how "a complex set of complementary HR practices" will fit into the overall structure (Ulrich 1997; Klass 2003: 43). Table 1 illustrates six options for SMEs to use in developing an HR support strategy. The following sections describe each option in more detail, including the benefits and limitations.

\section{Option I. No Change}

As with any decision-making process, there is always the option to maintain status quo. Having no formal HR support or strategy is typical of a small business with a very small employee base, perhaps one or two employees, or no employees. Once a company begins to build an employee base, even without a formal HR support strategy, administrative functions such as payroll, worker's compensation insurance, and training, even if informal, are necessary. These functions are the responsibility of the businessowner or manager when there is no other HR support.

Creating and implementing a support program where none exists does require some initial finances, and the main benefit for not utilizing a formal HR support strategy is that there is no additional financial outlay.This is often appealing to very small businesses that are conserving cash and monitoring their investments closely. For many small businessowners, keeping all aspects of the business in their control is also attractive when the business is in its start-up or initial growth phase.

Despite what appears to be a low to no-cost strategy, the time that the businessowner or manager spends focusing on the administrative side of HR is very expensive and detrimental to the business strategy. To quantify this, a businessowner needs to take his/her own hourly wage into consideration. If the businessowner were his/her own employee, making that salary, would it be efficient to use his/her time on administrative functions? Typically the answer is no, because implementing the business plan is much more critical than the administration. For the businessowner/manager, running the business is the only efficient use of time; administrative tasks are essentially busy work.

If a business is to carry the liability of employing a workforce, worker's compensation insurance is a legal necessity. Keeping premiums low is a function of quality safety training as part of an overall training program. When there is no HR support, businessowners/managers have to spend significant amounts of time training employees themselves. Even when a skilled workforce is employed, there is still an adjustment or orientation phase that employees experience. Without support, employees may experience decreased enthusiasm and increased frustration during this phase. It is much more difficult, therefore, for overtaxed businessowners to focus on employee satisfaction and retention without some form of HR strategy.

The biggest liability for a business with no HR strategy is the possibility of illegal actions, whether they are intentional, and lawsuits. As illustrated by the existing HR literature, businessowners/managers do not typically have the training, knowledge, or experience to know how to appropriately administer HR. Most employers know that it is not legal to hire an employee in the United States without either legal residency status or proper worker's permit documentation. However, employers may not know how to appropriately ask for this information, how to conduct a background screening, what kinds of questions are appropriate and legal to ask in an interview setting, or how to negotiate employment contracts and salaries. All of these questions require some degree of expertise in labor laws and HR administration.

\section{Option II. Staff Assume HR Work}

The second option, staff assume HR work, entails expecting other employees to take on HR responsibilities. This can be a risky strategy. It is rare that employees who lack HR training and experience will be able to effectively execute even the most basic HR tasks such as recruiting, hiring, training, and payroll (Wager and Langrock 2003b). Town Grocery, one particular firm with more than 350 employees implemented this strategy by asking the general manager, who has no formal HR training, to train individual administrative employees to take on various HR responsibilities. One employee in the finance department is responsible for payroll, another employee whose main job function is to oversee the inventory tracking process, is now also responsible for the initial hir- 
ing paperwork for all new hires. New employees who are "register trained," go through a three-day training process run by department supervisors. There is no training program for other employees, who essentially learn their job functions by trial and error. Because this firm promotes from within, even managers lack adequate training in core competencies such as buying and merchandising. Most of their skills are learned from working with distributors and by monitoring department sales to determine if the current merchandising strategy is successful (Ghassemieh 2004a).

\section{Table 1. Pros and Cons of HR Options for Small and Medium-Sized Enterprises}

\begin{tabular}{|c|c|c|c|c|c|}
\hline Option & & Descriptor & Recent Research & Primary Benefits & Major Limitations \\
\hline $\begin{array}{c}\text { I } \\
\text { No change }\end{array}$ & $\circ$ & $\begin{array}{l}\text { Implement no formal HR } \\
\text { support or strategy }\end{array}$ & $\begin{array}{l}\text { Gelade and Ivery (2003) } \\
\text { Mathis (2003) } \\
\text { Shutan (2003) }\end{array}$ & $\begin{array}{l}\text { No investment required } \\
\text { Maintains owner/ } \\
\text { manager's control over all } \\
\text { aspects of the business }\end{array}$ & $\begin{array}{l}\text { Owner/manager handles all } \\
\text { HR functions } \\
\text { Potential legal } \\
\text { ramifications } \\
\text { Reduced morale }\end{array}$ \\
\hline $\begin{array}{c}\text { II } \\
\text { Staff assume HR duties }\end{array}$ & $\circ$ & $\begin{array}{l}\text { Expect other employees to } \\
\text { take on HR responsibilities. } \\
\text { Tasks fragmented and } \\
\text { delegated to management } \\
\text { or lower level employees }\end{array}$ & $\begin{array}{l}\text { Becker et al. (2001) } \\
\text { Davidson (2003) } \\
\text { Wager and Langrock (2003a) } \\
\text { Klass et al. (2002) }\end{array}$ & $\begin{array}{l}\text { Limited financial outlay } \\
\text { required } \\
\text { Career-building potential } \\
\text { via staff cross-training } \\
\text { Reward opportunity for } \\
\text { growth and development }\end{array}$ & $\begin{array}{l}\text { Lack of adequate HR } \\
\text { training } \\
\text { Distracts managers from } \\
\text { focus on business strategy } \\
\text { Unclear "point-person" for } \\
\text { grievances }\end{array}$ \\
\hline $\begin{array}{c}\text { III } \\
\text { Hire HR Manager and Build Function }\end{array}$ & $\circ$ & $\begin{array}{l}\text { Hire a professional HR } \\
\text { Manager (i.e., who has HR } \\
\text { certification or an MBA } \\
\text { degree) }\end{array}$ & $\begin{array}{l}\text { Becker et al. (2001) } \\
\text { Lee (2002) } \\
\text { Fitz-Enz and Davidson (2002) } \\
\text { Davidson (2003) }\end{array}$ & $\begin{array}{l}\text { Highly trained expert is on } \\
\text { management team } \\
\text { Gives SMEs a competitive } \\
\text { edge } \\
\text { Includes HR in strategy } \\
\text { decision-making } \\
\text { Can prevent mistakes that } \\
\text { have financial and legal } \\
\text { consequences } \\
\text { Frees-up time for top-level } \\
\text { managers to run business }\end{array}$ & $\begin{array}{l}\text { Expensive } \\
\text { Difficult to find highly } \\
\text { qualified professionals who } \\
\text { want to work in firms with } \\
<100 \text { employees }\end{array}$ \\
\hline $\begin{array}{c}\text { IV } \\
\text { Hire HR consultant }\end{array}$ & $\circ$ & $\begin{array}{l}\text { Hire a temporary HR } \\
\text { consultant } \\
\text { Can be on an as-needed } \\
\text { basis }\end{array}$ & $\begin{array}{l}\text { McGarvey (1999) } \\
\text { Wager and Langrock (2003a) }\end{array}$ & $\begin{array}{l}\text { Can limit amount of } \\
\text { responsibility given to } \\
\text { consultant, retaining SME } \\
\text { control } \\
\text { Neutral third party to } \\
\text { consult for employee } \\
\text { relations' advice } \\
\text { Can hire on a temporary or } \\
\text { as-needed basis } \\
\text { Can prevent mistakes that } \\
\text { lead to financial and legal } \\
\text { ramifications } \\
\text { Having a person dedicated } \\
\text { to employee retention and } \\
\text { satisfaction frees up time } \\
\text { for top-level managers to } \\
\text { run business }\end{array}$ & $\begin{array}{l}\text { Full liability remains SME } \\
\text { responsibility } \\
\text { Selecting a consultant that } \\
\text { fits the needs of the SME. } \\
\text { Potentially costly }\end{array}$ \\
\hline $\begin{array}{c}\mathbf{V} \\
\text { Outsource HR to PEO }\end{array}$ & 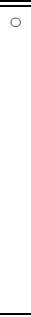 & $\begin{array}{l}\text { An HR service firm, such } \\
\text { as a PEO, will take on full } \\
\text { gamut of responsibility and } \\
\text { liability for hiring, training, } \\
\text { firing, as well as other } \\
\text { employee issues }\end{array}$ & $\begin{array}{l}\text { Neal (2000) } \\
\text { Lee (2002) }\end{array}$ & $\begin{array}{l}\text { PEOs economies of scale in } \\
\text { negotiating benefits } \\
\text { packages with major } \\
\text { carriers } \\
\text { PEO will take on full } \\
\text { liability and responsibility } \\
\text { With some vendors, can } \\
\text { choose which functions to } \\
\text { outsource }\end{array}$ & $\begin{array}{l}\text { Need to spend time } \\
\text { researching the best vendor } \\
\text { for SME's industry \& } \\
\text { company needs } \\
\text { Give up all employee } \\
\text { responsibilities to SME } \\
\text { If vendor goes out of } \\
\text { business, difficult to regain } \\
\text { employee information } \\
\text { May interfere with internal } \\
\text { relationship of HR and } \\
\text { Mgt/EEs }\end{array}$ \\
\hline $\begin{array}{c}\text { VI } \\
\text { Electronic HR (eHR) }\end{array}$ & $\circ$ & $\begin{array}{l}\text { Provides eHR support for } \\
\text { functions (e.g., online } \\
\text { training, benefits self- } \\
\text { management) } \\
\text { Can be used in conjunction } \\
\text { with other HR options to } \\
\text { create a complete package }\end{array}$ & $\begin{array}{l}\text { Friesen (2003) } \\
\text { Greengard (2003) } \\
\text { Hammers (2003) } \\
\text { Cohen (2004) }\end{array}$ & $\begin{array}{l}\text { Minimizes administrative } \\
\text { functions } \\
\text { Allows employees to be in } \\
\text { control of their own } \\
\text { benefits selections } \\
\text { Managers free to focus on } \\
\text { other priorities } \\
\text { When used in conjunction } \\
\text { with HR consultant, frees } \\
\text { consultant to focus on } \\
\text { employee relations } \\
\text { Online traceable training } \\
\text { Retains employee records }\end{array}$ & $\begin{array}{l}\text { SMEs still liable } \\
\text { Employees need to have } \\
\text { some expertise in benefits } \\
\text { enrollment } \\
\text { No live person to access } \\
\text { when all of HR is } \\
\text { electronic } \\
\text { Employees can get bored } \\
\text { with online training tools } \\
\text { Can be costly to implement } \\
\text { and administer }\end{array}$ \\
\hline
\end{tabular}

1. For a link to a downloadable sample page PEO contract, visit Applied Staffing Solutions' website at: http://www.appstaff.com/employers_employee-Leasing.php. 
Asking employees to take on specific HR tasks is a lowcost strategy that is very appealing to SMEs. Offering employees the opportunity to take on additional challenges can be rewarding for the employees, and can allow for employee growth and development. If SMEs provide proper training for these tasks, it is possible that employees can successfully implement aspects of administrative HR functions.

Although asking existing employees to take on various HR responsibilities requires almost no additional financial outlay, there are some clear drawbacks to this strategy. Fragmenting HR tasks creates confusion among employees. When employees are not sure of who to talk to when there is a grievance, they turn to top managers who are often out of touch with day-to-day departmental functions (Wager and Langrock 2003a; Becker et al., 2001). As a result, top managers' time is taken away from focusing on core business strategies and decisions. (Davidson 2003; Klass et al. 2002; Becker et al. 2001). Instead, managers are spending a significant amount of time handling employee concerns ranging from payroll mistakes to scheduling conflicts, as seen at Town Grocery. Furthermore, deficiencies in HR knowledge, in particular legal compliance, could lead to costly mistakes.

Overall, asking employees who have no formal HR training to take on HRM tasks is not the safest option; however, there are some measures that SMEs can take to protect themselves. Providing training is the most obvious and easiest way to support employees who are taking on HR responsibilities in addition to their regular duties. Investing in HR workshops or classes that will help employees to understand the compliance issues related to the functions they are now responsible for is a wise choice, and can help prevent costly mistakes. Giving employees access to the resources that will help them make better hiring decisions, helping them understand simple tasks, such as document retention schedules, and creating a communication structure for employee questions and concerns, will also save time for SME managers as well as help to develop a stronger team.

\section{Option III. Hire HR Manager}

Hiring a full-time HR professional can be very expensive for a small business with limited resources (Lee 2002). Annual salaries for HR professionals range from $\$ 50,000$ to $\$ 104,000$ a year (Saratoga Institute 2003). Typically, HR professionals have formal training and specialization in the HR sector. Most have HR certification or master's degrees, either a general Human Resources degree, or with a particular emphasis such as employee training. Many HR professionals have master's degrees in business administration (Anonymous 2004). Because of these credentials, professionals serve as strong strategic business partners and tend to be included in top- level management decisions (Davidson 2003; Becker et al., 2001).

As HR functions become more and more important to a company's overall strategy and sustainable competitive advantage, employing full-time HR professionals will give SMEs a strategic edge for competing with large and small competitors (Fitz-Enz and Davidson 2002; Davidson 2003; Becker et al., 2001). Moreover, HR professionals come to the business with the training, knowledge, and expertise that will help SMEs avoid common HR mistakes. Lawsuits and highcost worker's compensation claims can be prevented by including such expertise as part of the management team. Another advantage is having someone in house to handle employee incentive programs, such as employee recognition, team-building activities, and other activities that benefit employee satisfaction (Gelade and Ivery 2003; Mathis 2003; Shutan 2003).

According to the Saratoga Institute (2003), the industry standard for HR professionals is between one full-time HR employee per 90 to 100 employees. For small businesses with fewer than 100 employees, hiring a full-time HR professional is difficult to justify, given the high cost. However, SMEs with 100 employees or more will benefit from the expertise, training, and strategic partnership of having an HR professional on staff.

\section{Option IV. Hire HR Consultant}

It is difficult to tap into information on HR consulting without talking to a consultant or being affiliated with a consulting firm. However, SMEs can research different consulting firms to determine what types of services are offered and the associated costs. An online search of various HR firms servicing SMEs shows that, in general, HR consultants advise clients on specific problems or needs, such as worker's compensation claims, sexual harassment suits, and specific employee issues or situations.

For example, one particular insurance company in Northern California, with 45 employees is dealing with some difficult employee relations decisions. Until recently, the firm decided that HR administrative functions would be the responsibility of its office manager, while a temporary HR consultant would handle training and HR compliance on a once-a-year basis. However, as the firm's operations have grown, its office manager has become overburdened, and because of some of the employee-related situations, it was inappropriate for her to be involved with handling these grievances. As a result, an HR consultant was asked to come in once a week to handle employee grievances, mitigate discipline issues, act as an advisor in worker's compensation claims, handle compliance issues, and help maintain employee satisfaction. The consulting fee is $\$ 100$ an hour, which does not include the cost of transportation, paperwork, or 
any other additional charges. HR consultant costs vary between companies, and depend heavily on the types of services an SME needs (Ghassemieh 2004b).

Hiring an HR consultant has the benefit of having access to a live person who is an expert in handling HR issues. Consultants have easy access to legal information, compliance laws, and other HR resources that are costly to set up (Ghassemieh 2004b). There is the added benefit of having a third-party person who is not directly affiliated with the internal business to handle employee issues, such as chronic tardiness or absenteeism, interpersonal conflicts, performance appraisals, worker's compensation claims, sexual harassment claims, and employee satisfaction. Furthermore, SME managers and businessowners retain control and responsibility of their organization's structure and HR operations, such as hiring, firing, and benefits, while having access to a professional for more complex issues that require further training and experience.

Some of the limitations of hiring an HR consultant include retaining full employee liability. Unlike outsourcing HR (Option V), HR consulting firms do not take on any legal responsibility for lawsuits or compliance failures that may arise. They work strictly in an advisory role, and tend to include liability disclaimers in their hiring contracts. Although having an HR consultant available to employees and managers allows for human contact, it takes time and training for consultants to familiarize themselves with the operations and organization of the businesses for which they consult (Wager and Langrock 2003b). Depending on the consultant and the firm, the costs may be too high for some SMEs who do not have adequate finances.

\section{Option V. Outsource HR}

The HR outsourcing industry, which services small and large businesses, was projected to grow to a $\$ 37.7$ billion industry by 2002 (Lee 2002).According to Gartner Inc., a research and advisory firm, the outsourcing industry has a 9.5 percent growth rate and was actually at $\$ 110$ billion in 2002 , with a $\$ 173$ billion projection for 2007 (Gartner Inc. 2003). Because the industry is growing so rapidly, types of vendors and their offerings are changing as well. Most outsourcing vendors provide solutions for recruitment, compensation planning, stock options administration, training, payroll, employee benefits, and risk management.

Professional Employer Organizations (PEO) is the most widely used form of outsourcing today. Notable PEO firms include Administaff, CheckPoint HR, Tri State PEO, and ADP Total. The PEO option is attractive because vendors take on the liability associated with carrying employees. Essentially, PEO vendors become co-employers with their clients because they assume responsibility for hiring, firing, and employee salaries. It is important for SMEs to fully research a
PEO before signing a contract because not all PEOs take on the same level of legal responsibility or liability (BuyerZone.com 2002). Understanding the differences between vendors and the needs of the business are key factors in the decision to outsource. The cost of using an outsourcing vendor will vary by vendor and industry, but in general, "the client pays the PEO the actual cost of wages and benefits plus an administrative fee of between 2 and 6 percent of payroll to cover the cost of the HR services" (Klass 2003: 44; Hirschman 1997).

There are many benefits for SMEs who contract with PEOs, including the advantage of economies of scale. Many SMEs do not offer desirable benefits packages to employees because of the associated costs. However, a PEO hires and manages employees for many clients giving PEOs the kind of bargaining advantage that most small businesses do not have (Klass 2003). By virtue of having large numbers of employees, PEOs can negotiate benefits packages with HMOs, PPOs, and other benefits providers, which are similar to the kinds of packages that large companies are able to offer. This advantage is desirable for SMEs as well as their employees. Another substantial benefit to employers is the time savings that come from not having to research federal and state employment laws. Since PEOs are responsible for compliance in hiring and firing practices, small businessowners and managers are free from the stress, cost, and time associated with following up with and measuring internal HR compliance (Lee 2002).

Although the benefits of outsourcing are desirable, SMEs must carefully research vendors before deciding to hand over employee information. The cost and time to set up the SMEPEO relationship varies by industry and by vendor; however, there are several factors affecting the establishment of the SME-PEO relationship that heavily influence cost and time. Some of the important factors include trust in the SME-PEO relationship, clear and open communication channels between the SME and PEO, tenure of PEO representatives, and SME management's understanding of PEO services prior to contracting. Trusting a PEO is critical since SMEs are placing confidential and sensitive data in their care. What happens if a PEO goes out of business? Will the SME have access to its own employee information? Questions such as these must be addressed when devising a contract so that SMEs can protect themselves against losses.

\section{Option VI. Electronic HR}

The use of electronic HR (eHR) is a growing trend for large corporations. eHR was introduced 10 years ago, first as a software package that was installed on each employee's computer (Cohen 2004). The initial system promised high value, but was somewhat disappointing as it was viewed as a "glorified [benefits] enrollment form" (Cohen 2004: 27). Since that time, eHR has expanded to include benefits, payroll systems, 
tracking of employee records, vacation time, and gainsharing plans. These interactive tools have advanced so much that many eHR systems are simple enough that IT does not have to be involved in web administration (Greengard 2003). Because of advancements in eHR technology, it is becoming more affordable for SMEs to use this option as well.

Similar to outsourcing, eHR is beneficial because firms can delegate administrative and technical functions to the eHR system, thereby reducing some of their HR costs. Employees are becoming more Internet savvy, and workplace culture has evolved to expect Internet skills (Greengard 2003). SME managers and owners no longer have to be involved in employee benefits selections or payroll tasks with eHR tools.Also, training is greatly simplified and easier to track with online training functionality. Employees can manage their own training through online instruction modules that can teach employees in a virtual business environment. The benefit to SMEs is the ability to monitor employee training through online test scores and employee files that are stored on the system.

One limitation argued by some consultants is that eHR systems are merging internal and external recruiting environments, making it more difficult for employers to limit recruitment and promotion opportunities to internal employees (Friesen 2003). This is a benefit to employers who are looking for a larger pool from which to select employees; howev- er, employers who have a policy that only allows promotion from within will have a more difficult time (Friesen 2003). Similar to fully outsourcing HR, solely using eHR requires employees to have computer literacy, while limiting their access to HR as there is no one-on-one personal interaction. Although eHR is becoming more cost effective, in some cases it can cost millions to implement a full eHR initiative with multiple licensing and applications (Hammers 2003). eHR also requires that employees become experts in benefits options, causing SME managers and owners to also become experts in order to answer questions and offer guidance. In addition there are some training limitations as employees often have difficulty maintaining interest in ongoing online instructional modules (Ghassemieh 2004b).

\section{Implications for Researchers and Practitioners}

Small businesses around the globe are looking for experts and resources that can direct, advise, and offer guidance in implementing HR support for their employees (Kok and Uhlaner 2001; Jackson 2002). Owners and managers of SMEs lack training and experience in HR-related functions. Although prior researchers have examined some of the HR options available to SMEs, no one resource has been created to include a matrix of the entire range of HR options. As

\section{Table 2. HR Decision-Making Matrix for Small and Medium-Sized Enterprises}

\begin{tabular}{|c|c|c|c|c|c|}
\hline \multirow{2}{*}{ Option } & \multicolumn{5}{|c|}{ Considerations } \\
\hline & $\begin{array}{l}\text { Hiring and } \\
\text { Recruitment }\end{array}$ & Training & $\begin{array}{c}\text { Benefits and } \\
\text { Compensation }\end{array}$ & $\begin{array}{l}\text { HR Metrics and } \\
\text { Enterprise Value }\end{array}$ & $\begin{array}{c}\text { Estimated Cost } \\
\text { Factor }\end{array}$ \\
\hline $\begin{array}{c}\text { I } \\
\text { No change } \\
\end{array}$ & No impact on strategy & None & No impact & $\begin{array}{c}\text { Potentially negative } \\
\text { impact }\end{array}$ & Low \\
\hline $\begin{array}{c}\text { II } \\
\text { Staff assume HR } \\
\end{array}$ & No impact on strategy & $\begin{array}{l}\text { Limited, some cross- } \\
\text { training of existing } \\
\text { staff }\end{array}$ & $\begin{array}{c}\text { Potential } \\
\text { advancement for } \\
\text { existing staff }\end{array}$ & $\begin{array}{c}\text { Potentially negative } \\
\text { impact }\end{array}$ & Low \\
\hline $\begin{array}{c}\text { III } \\
\text { Hire HR Manager and } \\
\text { Build Function }\end{array}$ & $\begin{array}{l}\text { Makes HR part of } \\
\text { strategy }\end{array}$ & $\begin{array}{l}\text { Limited cost- } \\
\text { effectiveness for firms } \\
\text { with }<100 \text { employees }\end{array}$ & Favorable impact & $\begin{array}{c}\text { Potentially favorable } \\
\text { impact }\end{array}$ & High \\
\hline $\begin{array}{c}\text { IV } \\
\text { Hire HR consultant }\end{array}$ & $\begin{array}{l}\text { Makes HR part of } \\
\text { strategy }\end{array}$ & $\begin{array}{l}\text { Limited cost- } \\
\text { effectiveness for firms } \\
\text { with }<100 \text { employees }\end{array}$ & Favorable impact & $\begin{array}{c}\text { Potentially favorable } \\
\text { impact }\end{array}$ & Moderate to high \\
\hline $\begin{array}{c}\mathbf{V} \\
\text { Outsource HR to PEO }\end{array}$ & $\begin{array}{l}\text { Makes HR part of } \\
\text { strategy }\end{array}$ & Cost-effective & Favorable impact & $\begin{array}{c}\text { Potentially favorable } \\
\text { impact }\end{array}$ & Moderate to high \\
\hline $\begin{array}{c}\text { VI } \\
\text { Electronic HR (eHR) } \\
\end{array}$ & No impact on strategy & $\begin{array}{c}\text { Limited cost- } \\
\text { effectiveness for firms } \\
\text { with }<100 \text { employees }\end{array}$ & Unknown impact & Unknown impact & Moderate to high \\
\hline
\end{tabular}


depicted in Table 2, the proposed HR decision-making matrix model can help SMEs choose an HR strategy option and find a configuration that is most supportive of their situations or stages of growth.

\section{Application of the HR Decision Matrix Model}

The HR decision matrix model is helpful to SMEs in selecting an HR strategy that will best fit their overall business strategy and size of organization. Though not applicable in every situation, for most businesses with less than 100 employees, Option 1: No Change or Option II: Staff Assume HR Duties are most appropriate. In both of these options, the owner and general management will continue to make the hiring and recruitment decisions, so there is no impact on business strategy. For training, with Option 1, informal on-the-job training will be provided, but with Option II, internal staff will take on some of the training duties, including cross-training of existing staff. Regarding compensation and benefits, with Option 1 , there is no impact on existing business strategy, but Option II could provide potential advancement for existing staff who assume HR responsibilities. Unfortunately, with both of these options there is a potentially negative impact on the overall HR metrics and enterprise value-especially if the owner and general management spend too much time caught up in the administrative portions of HR. Conversely, they could spend too little time on HR issues and find they are not in compliance with local or federal labor law issues. The upside of both Options I and II for businesses with less than 100 employees is that the cost factor is quite low.

A caveat to the above recommendation is that in SMEs with less than 100 employees that operate in industries where litigation is rampant, a safer solution would be Option IV: Hire HR Consultant-but perhaps on a limited basis to keep costs low. The HR consultant could provide the legal counsel needed, but would not burden the small company with the overhead of a full-time HR professional.

For businesses with more than 100 employees, the two most obvious solutions are Option III: Hire HR Manager or Option V: Outsource HR to PEO. The selection of the most appropriate option depends, in most part, on the culture of the organization and the philosophy of the management team. Outsourcing of HR to a PEO relieves the management team of much of the stress of HR administrative functions, but also distances management from certain employee relation issues. For fast-paced, more formal environments, this may be a good choice. However, for SMEs which pride themselves on creating a family environment in which management knows a lot about each employee and wants to promote a more cohesive, team-oriented environment, the investment in a full-time HR professional may be the best choice. This will not only be a safeguard for legal issues, but will also send a message to employees that HR is valued, because the function is part of the company family. It may also be more satisfying for employees to have a "real person" on site with whom they can speak face-to-face, rather than telephoning an outside firm for HR support.

For larger firms, both Options III and V do make HR part of the business strategy for recruiting and hiring, and can have a favorable impact on training, compensation, benefits, HR metrics, and enterprise value (See Table 2). The downside is the moderate to high cost factor for implementation.

As SMEs grow in size, reaching the 1,000 employee mark, this might signal a good time to investigate Option VI: Electronic HR - but not as a solo solution. eHR works well in combination with both Options IV and V, and over the long run can save a lot of time by providing answers to common employee HR questions online.This option, however, generally does not make financial sense for a company with fewer than 100 employees, as the systems require an initial capital outlay for implementation.

Finally, it is quite feasible for a larger SME with 1,000 or more employees to use a combination of the six HR options, as it progresses in its organizational development and size. For example, when the firm was smaller, with less than 100 employees, it may have elected to use Option II: Staff Assume HR Role. However, as it grew in employee size, it may have elected to hire a full-time HR Manager (Option III). Later it may have added an eHR system (Option VI), and outsourced payroll and benefits to a PEO (Option V). On occasion, it may elect to bring in an HR consultant (Option IV) to assist with training or other HR issues on an as-needed basis.

\section{Limitations and Areas for Furtber Exploration}

SMEs who elect to implement HR support should continue to rely on an HR professional to help select an option that meets a particular set of needs and contributes to sustainable competitive advantage. In that vein, managers and owners of SMEs will need to conduct further research (i.e., which vendor to choose, what kind of eHR software is appropriate, which consultant or professional to hire). Future academic research is also needed to show the costs and benefits of adopting one option over another, and under what conditions one or more options is likely to lead to increased enterprise value. Since the HR decision matrix model is presented here as a conceptual model, further empirical tests are warranted. Conducting in-depth structured interviews after the HR decision matrix model has been used to make HR support decisions would help to test the utility of the model. Finally, there appear to be opportunities to document HR practices in SMEs in developing nations that may or may not have ready access to the consulting, outsourcing, and eHR options presented in the model. 


\section{Endnote}

${ }^{1}$ Town Grocery's name has been disguised at management's request.

\section{References}

Anonymous. 2004. Leadership:A path to HR Career satisfaction. HR Focus 81, 1: 52-3.

Appelbaum, H., and Kamal, R. 2000. An analysis of the utilization and effectiveness of non-financial incentives in small business. The Journal of Management Development 19, 9/10: 733-763.

ASTD. 2003. ASTD industry report. Available at http://www.astd.org/astd.

Augustine, L., and Wilson, M. 1994. Human resource systems and sustained competitive advantage:A competency-based perspective. Academy of Management Review 19, 4: 699.

Arbaugh, J. B., Cox, L.W., and Camp, S. M. 2004. Employee equity, incentive compensation, and growth in entrepreneurial firms. New England Journal of Entrepreneurship 7, 1:15-25.

Becker, B., Huselid, M., and Ulrich, D. 2001. The HR Scorecard: Linking People, Strategy, and Performance. Boston, Massachusetts: Harvard Business School Press.

Becker, B., and Huselid, M. 2003. Measuring HR? HR Magazine 48, 12: 56-61.

Burke, W. 1997. What Human Resource practitioners need to know for the twenty-first century. Human Resource Management 36, 1: 71 .

BuyerZone.com. 2004. PEO \& Employee Leasing Quotes from Multiple Vendors.Available at: http://www.buyerzone.com/personnel/peo/qz_questions_851.jhtml.

Case, J. 2001. Counting companies: State of small business 2001. Inc. Magazine, May 15.Available at: http://www.inc.com/articles/details/0,3532,CID22603_REG3,00.html.

Cassell, C., Nadin, S., Gray, M., and Clegg, C. 2002. Exploring human resource management practices in small and mediumsized enterprises. Personnel Review 31(5/6): 671-692.

Cohen,A. 2004. New electronic HR tools are hitting their stride. National Underwriter 108, 5: 27-28.

Davidson, B. 2003. Reviewing corporate financials show how HR measures up. Employee Relations Today (Spring).Available at: www.interscience.wiley.com.

Devins, D., and Johnson, S. 2003. Training and development activities in SMEs. International Small Business Journal 21 , 2: 213.

Fitz-Enz, J., and Davidson, B. 2002. How to Measure Human Resource Management. New York: McGraw Hill.

Friesen, B. 2003. Is your client really ready for eHR? Consulting to Management 14, 3: 27.

Gartner Inc. 2003. SMBs: The Biggest Little Outsourcing Market in the World.

Gelade, G., and Ivery, M. 2003. The impact of human resource management and work climate on organizational performance. Personnel Psychology 56, 2: 383.

Gering, M. 2003. Keep them off balance. Financial Management: 15-17.

Ghassemieh, G. 2004a. Personal Interview with Tom Scott, Rohnert Park, CA. January 2004.

Ghassemieh, G. 2004b. Personal Interview with Kristen Holden, Rohnert Park, CA.April 2004.

Graham, M., and Welbourne,T. 1999. Gainsharing and women's and men's relative pay satisfaction. Journal of Organizational Bebavior 20, 7: 1027-1042.

Greengard, S. 2003. The dawn of digital HR. Business Finance 9, 10:55-59.

Hammers, M. 2003. Technology brings employees the Hartford experience. Workforce 82, 4: 42-45.

Harel, G., and Tzafrir, S. 1999. The effect of human resource management practices on the perceptions of organizational and market performance of the firm. Human Resource Management 38, 3: 185-199.

Hill, E. J. 2004. Towards More-and better-choices in health care: The AMA on HSAs, Health system reform \& the uninsured. Executive Speeches 19, 3: 23-27.

Hirschman, C. 1997. All aboard:The boom in employee leasing may bring good career opportunities for HR professionals. HR Magazine 42: 80-86. 
Hornsby, J., and Kuratko, D. 2003. Human resource management in U.S. small business: a replication and extension. Journal of Developmental Entrepreneurship 8, 1:73.

Huselid, M. 1995. The impact of human resource management practices on turnover, productivity, and corporate financial performance. Academy of Management Journal 38, 3: 635.

Ibrahim,A. B., and Ellis, W. H. 1993. Entrepreneurship and small business management:Text, readings and cases. Dubuque, IA: Kendall/Hunt Publishing Company, 3-13.

Jackson, T. 2002. The management of people across cultures: valuing people differently. Human Resource Management 41, 4: 455-475.

Klass, B. 2003. Professional employer organizations and their role in small and medium enterprises: the impact of HR outsourcing. Entrepreneurship: Theory and Practice 28, 1:43-61.

Klass, B., McClendon, J., and Gainey,T. 2002. Trust and the role of professional employer organizations: managing HR in small and medium enterprises. Journal of Managerial Issues, 14, 1:31-48.

Kok, J., and Uhlaner, L. 2001. Organization context and human resource management in the small firm. Small Business Economics 17, 4: 273-291.

Krieger, H. 2003. Is a "Professional Employer Organization" in your future? The National Public Accountant 30-31.

Lee, M. 2002. Outsource Your HR: Payroll, benefits, hiring, firing, tax compliance-Erase those tasks from your to-do list by hiring an HR outsourcing firm. Entrepreneur Magazine.Available at: www.entrepreneur.com/article/0,4621,305528,00.html.

Mathis, R. 2003. Learning the language of business: A leading HR/benefits educator maintains that practitioners must learn to make a business case for their activities before it's too late. Employee Benefit News, University of Omaha (September 17).

MacMahon, J., and E. Murphy. 1999. Managerial Effectiveness in small enterprises: Implications for HRD. Journal of European Industrial Training 23, 1:25-35.

Porter, M. 1990. The competitive advantage of nations. New York:The Free Press.

Robbins, S. 2000. Essentials of organization behavior, 6th ed. Englewood Cliffs, NJ: Prentice-Hall.

Rowden, R. 2002a. The relationship between workplace learning and job satisfaction in U.S. small and midsize businesses. Human Resource Development Quarterly 23, 4: 407- 425.

Saratoga Institute. 2003. The Saratoga Review.Available at: http://www.pwcservices.com/saratoga-institute/index.html.

Schermerhorn, J. R. 2001. Management updated 2001, 6th ed. New York: John Wiley and Sons, Inc.

Shutan, B. 2003. What small business needs to know about pay and benefits. Employee Benefit Plan Review 57, 7: 6-9.

Ulrich, D. 1997. Measuring human resources:An overview of practice and a prescription for results. Human Resources Management 36, 3:303-320.

Vinten, G., Lane, D., and Hayes, N. 1997. People management in small and medium-sized enterprises. Management Research News 20, 11:1-66.

Wager,T., and Langrock, L. 2003a. Small firms offline on Internet recruitment. Canadian HR Journal 16, 13: 5.

Wager,T., and Langrock, L. 2003b. How small firms train employees. Canadian HR Journal 16, 17: 5.

Welbourne, T., Balkin, D., and Gomez-Mejia. 1995. Gainsharing and mutual monitoring: a combined agency-organizational justice interpretation. Academy of Management Journal 38, 3: 881.

Welbourne, T., and Cyr, L. 1999a. Using ownership as an incentive. Group \& Organization Management, 24, 4: 438-460.

Watson, J., and Everett, J. E. 1996. Do small businesses have high failure rates? Journal of Small Business Management 11, 3 : 74-96.

Weatherly, L. 2003. Human Capital-The elusive asset. HRMagazine 48, 3: S1-10. 


\section{About the Authors}

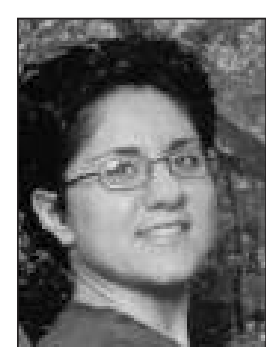

GOLBOU GHASSEMIEH (curlybou@yahoo.com) completed her B.A in psychology at the University of California, Berkeley in May 2000. She has three years of internship experience, specializing in training, orientations, assessments, and growth and development. She went on to work for Agilent Technologies, contributing training materials and processes to internal customers and employees. Ms. Ghassemieh also has retail management experience where she was responsible for HR management, training, employee development, and performance management. She also worked as an executive recruiter for a boutique search firm in Northern California while completed her master's in business administration degree from Sonoma State University in May 2004. She currently works as an HR manager for a fortune 500 company and is responsible for staffing, development, retention, and brand strategies.

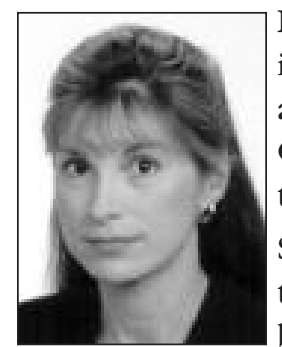

ELIZABETH "LIZ" THACH (liz.thach@sonoma.edu) is a management professor and consultant specializing in human resource development, wine business strategies, organizational behavior, leadership and international business. She has more than 18 years of experience, including HR management and executive positions with Compaq, Amoco, Texas Instruments, and AT\&T Broadband. She has worked in more than 15 countries and has taught thousands of employees worldwide.

She holds a doctorate in human resource development from Texas A\&M University, and has published more than 50 articles, three book chapters, and one book. She frequently consults in the wine, telecomm, and biotech industries, and teaches HR, leadership and wine business classes at Sonoma State University in the School of Business.

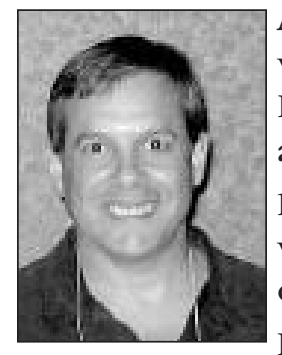

ARMAND GILINSKY, JR. (armand.gilinsky@sonoma.edu) is professor of business at Sonoma State University, where he teaches strategy and entrepreneurship. In recent years he has served as director of SSU's Entrepreneurship Center, Wine Business Program, and Small Business Institute. He previously held teaching appointments at the Harvard Business School, CSU Hayward, and Northeastern University.

Dr. Gilinsky has had extensive consulting experience with more than 30 companies, including members of the wine industry. His areas of specialty include strategic planning and venture planning. He has authored numerous business case studies and several articles on entrepreneurial strategy.

He holds the Ph.D. in business policy from Henley Management College/Brunel University (London), and M.B.A. in finance from Golden Gate University, an A.M. in Education administration and policy analysis from Stanford University and an A.B. (honors) in English from Stanford University. 